\title{
Woman's Health Improvement through Lifestyle Modifications: Focus on Islamic Lifestyle
}

\author{
Mohammad Rabbani Khorasgani \\ Department of Cell and Molecular Biology \& Microbiology, Faculty of Biological Science \& Technology, University of Isfahan , Hezar Jerib Street \\ , Isfahan, Islamic Republic of IRAN
}

Corresponding author: Mohammad Rabbani Khorasgani, Department of Cell and Molecular Biology \& Microbiology, Faculty of Biological Science \& Technology, University of Isfahan, Hezar Jerib Street, Isfahan, Islamic Republic of IRAN

Received date: April 15, 2021; Accepted date: April 28, 2021; published date: May 31, 2021

Citation: Mohammad Rabbani Khorasgani. (2021) Woman's Health Improvement through Lifestyle Modifications: Focus on Islamic Lifestyle. J. Women Health Care and Issues, 4 (5); DOI:10.31579/2642-9756/057

Copyright: ( 2021 Mohammad Rabbani Khorasgani, This is an open access article distributed under the Creative Commons Attribution License, which permits unrestricted use, distribution, and reproduction in any medium, provided the original work is properly cited.

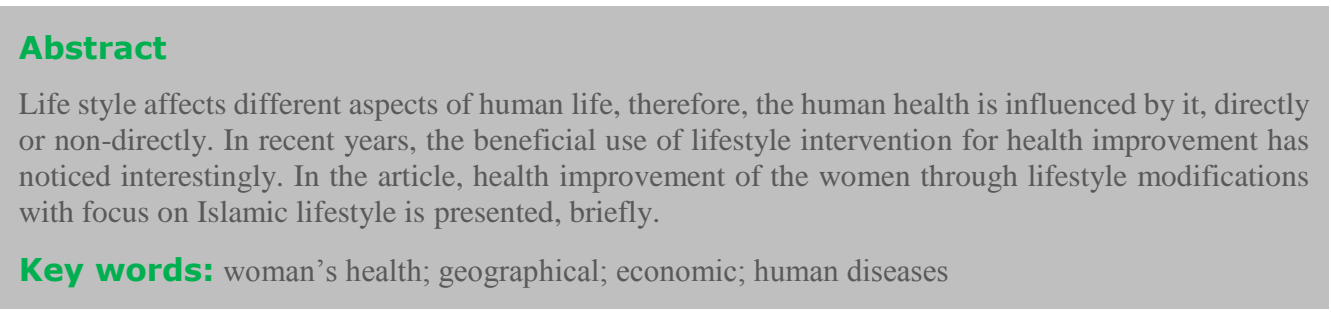

\section{Introduction}

Lifestyle as the way or style used by people in their life in special time and place, includes behaviors and functions of individuals. Life style is influenced by specific geographical, economic, political, cultural and religious factors. Lifestyle affects different aspects of human life. WHO, has estimated that $60 \%$ of related factors to individual health and quality of life are correlated to life style. Life style management may be regarded as effective action for health promotion.

The description of effects of lifestyle management specially Islamic lifestyle on improvement of woman's health would be regarded as the followings:

1. Influences of lifestyle on predisposition, development, exacerbation or prevention and control of human diseases.

Some of important diseases such as most cardiovascular diseases can be addressed by lifestyle-related risk factors such as unhealthy diet and obesity, physical inactivity, tobacco use, and harmful use of alcohol, and vice versus, some lifestyle-related factors such as: diet management, physical activity and good pattern of sleepiness and awaking may be beneficially effective in prevention and control of diseases.

2. Islamic lifestyle characteristics and their effects on human health Islamic lifestyle affects different aspects of human body and soul. Some important characteristics of Islamic lifestyle with potential effect on: human health are included.

2.1. The necessity of pay attention to spiritual and physical aspects of human together

2.2. Carefulness about human health and emphasis on pay attention to keep healthy and preventing harmful activities
2.3. Islamic nutrition style specially prohibition of potentially deleterious materials known as "Haram" substances eating

2.4. Insistence on: "prevention is better than cure"

2.5. Spiritual health strengthening with piety, abstinence "Taghva", reliance on Allah, tolerance and hopefulness for the future

2.6. Islamic family lifestyle especially encouraging the marriage

2.7. Insistence on acquisition of health- related sciences and underlining that: "for any pain, there is a cure"

2.8. The emphasis on the importance of knowledge-based medicine and preventing the non-scientific intervention on human health

2.9. The religious beliefs and practices including some private and /or communications and multidisciplinary works with beneficial health effects

2.10. The necessity of pay attention to the rights of others

\subsection{Islamic sex healthy lifestyle}

2.12. The properly time management between working, sleeping, spiritual duties and recreation and entertainment activities

2.13. Social lifestyle: Essential preparations to prevent people loneliness and social isolation such as: emphasis on marriage, religious and social duties: the care and support of parents and elderly people, visiting the sick, collective worship practices and etc.

\section{Specific principles in Islamic lifestyle for woman health}

3.1. Encouraging the marriage and regarding the family lifestyle as important principle for management of essential unit of community 
3.2. Sex as an essential and one of the most pleasurable things of the life and the Islamic guidelines for a healthy sex life for both men and women together

3.3. Not unrestrained sexual activity, nor sexual asceticism but legal sexual activities that restricted to marriage

3.4. Prohibition of unlawful and illicit relationships (adultery, pederasty and same-sex relationships)

3.5. Encouraging the chastity and forbidden of indecent behaviors

3.6. Forbidden sexual relationship during a woman's period

3.7. Prohibition of alcoholic beverages and therefore prevention of uncontrolled behaviors

3.8. Punishment for overt unlawful sexual relations and sex crimes

\subsection{Encourage having children}

3.10. The importance of pregnancy

3.11. Necessity of breastfeeding as an essential right of baby and a holy activity" Jihad" with excellent rewards from GOD and its instructions in Islamic lifestyle It is seemed that more multidisciplinary studies are necessary for explanation of powerful effect of healthy lifestyle on woman health.

\section{Conclusion:}

In-depth studies about "lifestyle and health" relationships with beneficial using of human experiences, cultural and religious teachings will be helpful for proper modifications in lifestyle to health improvement of women.
This work is licensed under Creative

Commons Attribution 4.0 License

To Submit Your Article Click Here: Submit Manuscript

DOI: $10.31579 / 2642-9756 / 057$
Ready to submit your research? Choose Auctores and benefit from:

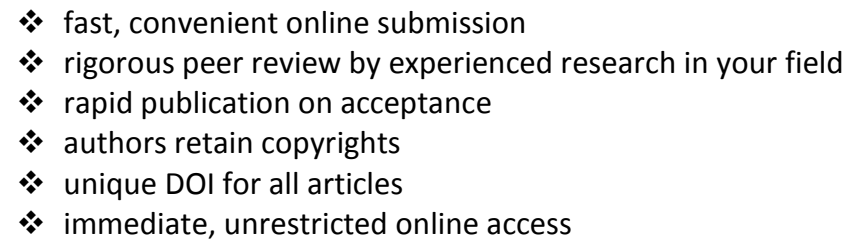

At Auctores, research is always in progress.

Learn more www.auctoresonline.org/journals/women-health-care-andissues- 